\title{
Conceptual foundations of the green finance mechanism: current experience and development trends
}

\author{
Saltanat Omurova ${ }^{1}$, Turar Koichuev ${ }^{2, *}$, and Meerim Koichueva ${ }^{2}$ \\ ${ }^{1}$ Kyrgyz National State University n.a. Zh. Balasagyn, Kyrgyzstan \\ ${ }^{2}$ National Academy of Sciences of the Kyrgyz Republic, Kyrgyzstan
}

\begin{abstract}
The principles of green finance and social investment are relevant directions not only from the point of view of studying practical experience, but also the formation of theoretical and methodological aspects of the conceptual platform of resource-saving technologies and sources of their financing. Today, the global transformation toward clean development requires a reconsideration of many aspects of economic activity, but it especially requires a reworking of the financial architecture of the global economy and a shift in emphasis from problems of economic efficiency to sustainability and resource conservation. In the global context, the issues of financing the universal greening of economic relations at every level require, firstly, the involvement of an increasing number of participants in this process, and secondly, they require not only a formal declaration of participation in the green movement, but also confirmation through the implementation of appropriate public policies in each of the fields of economic relations. Moreover, the supranational policy documents adopted at the 11th G20 Summit on September 4-5, 2016 in PRC have prioritized the green finance development at the national and regional levels to achieve the Millennium Development Goals or 17 Sustainable Goals. It should be noted that in the context of Russian practice the green finance mechanism is developing quite dynamically, there is a comprehensive redesign of the financial architecture and national features emerge that somehow identify the Russian financial system in the context of green finance and social investment, which undoubtedly acts as a relevant research area and requires approaches of an applied nature. Determination of the fundamental features and specifics of the green finance mechanism will allow to formulate a comprehensive program of effective transformation of the entire economy in the direction of green growth and sustainable development. This study attempts to systematize the conceptual foundations of green finance in modern transformational practice and identify the problem field of research, actualizing the most important aspects of the entire financial ecosystem from the perspective of rational choice and capital-saving production.
\end{abstract}

\footnotetext{
*Corresponding author: t.koychuev@gmail.com
} 


\section{Introduction}

Modern aspects of economic development are largely determined by trends in the field of green economy and sustainable growth. The global ideology of sustainable development is now universally accepted and modern economic policies of many states are formed on the basis of established principles of green growth. Undoubtedly, these trends are reflected in all types of economic activities and methods of their state regulation. As you know, in 1987 the UN Commission on Environment and Development proposed to consider the principle of organizing an economic system in which the consumption of natural resources should not exceed the ecosystems productivity and regeneration, exclude environmental costs and explicitly consider the interests of future generations, as a sustainable. In sustainable development, the improvement of the well-being of the Earth's population should be ensured through the introduction of sustainable consumption and production, and social and technical progress should be achieved only through environmentally aware measures. It is this principle that formed the basis of the sustainable development concept, and it was formulated by the economy founder of sustainable growth, W. Nordhaus. In exploring the factors of economic growth, W. Nordhaus, winner of the 2018 Nobel Prize in Economics, recognized back in the 1970s that the state of global climate and the environment had a direct impact on ensuring continued economic development. In his work, the author, based on an integrated model of relationship between economic growth and climate change, reached the conclusion that the total use of natural resources can be valued through a certain amount of greenhouse gas emissions, which affect the average air temperature and lead to climate change on the planet. In turn, the air temperature determines the multiplier corresponding to the environmental damage. As a result, total factor productivity falls due to environmental damage. And as empirical data analysis has shown, a brown economy focused on achieving only economic benefits without a rational approach to environmental protection can lead to serious environmental problems and long-term costs in terms of excessive consumption of non-renewable natural resources and lead ultimately to a global crisis not only in the environment, but also in the economy as a whole.

At the same time, green transformation and complete production reequipment to the principles of sustainable growth require quite a lot of effort, not only in terms of institutional costs, but also in determining the sources and principles of financing these transformations. In this regard, the logical consequence was the concept of green finance, which predetermined the mechanisms and tools that provide the necessary financial resources for the transformation of all types of relationships.

Understanding this problem allowed to formulate the green transformation principles and develop a conceptual policy for the transition from extensive and resource-inefficient economic growth to sustainable development and "green" economy. This was preceded by the following events: the heads of 167 states in 2015-2016 join the UN resolution on achieving the Sustainable Development Goals and sign the Paris Agreement on Reducing Greenhouse Emissions into the Atmosphere. In turn, declaring the transition to green growth and sustainable development requires a fairly serious financial injection. In particular, among the European leading countries in 2020, the investment gap only in the energy sector is estimated by experts at 500 million euros All this makes it necessary to revise the global architecture of the financial system and the emergence of new principles of green finance. The core idea of global cooperation and integration of financial and "green" issues is to link the procedures for solving global, regional and national natural-climatic and environmental problems with the tools of modern global financial markets and through "greening" of the global financial system to carry out the improvement of global finance and the environment. Thus, the relevance of research on this topic is due to climate and energy challenges, the solution of which requires significant financial injections through the reconstruction of the 
global financial system and the introduction of new innovative financial instruments for socially responsible investment.

\section{Materials and Methods}

The present study was conducted on the basis of empirical methods of description, interpretation and comparison, theoretical methods of formal and dialectical logic. Privatescientific methods were also used: the economic-dogmatic method and the method of interpreting the conceptual provisions of economic science.

The study's empirical basis consists of official reports and statistical data, as well as expert evaluations of specialists on the problem indicated

The key aspect of the studied terminology is "green finance", "green bonds" and "social investment". The most common approach to the definition of green finance is the approach according to which green finance refers to financial services focused on the implementation of economic activities to improve the environment, reduce the effects of global climate change and energy-efficient consumption of resources. Green bonds are a debt instrument for attracting investment projects in the field of climate change and its consequences, as well as improving energy efficiency, environmentally friendly transport, and the transition to a lowcarbon economy. And the concept of green bond is much broader than a climate bond, the name of which predetermined the scope of its provision in socially responsible investing.

Thus, all terminological changes should have been confirmed on the basis of unification of approaches to the green bonds identification and become a criterion for socially oriented investment projects, and moreover a methodological platform for the development of a conceptual national policy in the field of green finance.

\section{Results and Discussion}

As defined above, the ongoing changes on a global scale predetermined the creation in 2009 of the Climate Bonds Initiative (CBI), a non-profit international organization, which was initially focused on mobilizing a bond market in the amount of 100 trillion US dollars for investment projects focused on to tackle climate change.

It is necessary to point out that at present, there is still no unified approach to defining the principles and green criteria for an investment project according to which it can be classified as green. In particular, the Italian scientists R. Burrough, N. Ciamponi and V. Marini conducted a study on the existing standards in the definition of "green" finance and economic sectors, investment in which can be attributed to green investment. The authors of the study came to the conclusion that out of 11 economic sectors, 4 sectors can be classified as controversial or conditionally green:

1. "clean" energy, including nuclear power, large hydroelectric power plants, environmentally friendly fuel production, mining;

2. energy efficiency, including the energy efficiency of the use of fossil fuels;

3. transport, including rail;

4. pollution control and waste management (disposal and incineration of waste without the use of energy and gas).

At the same time, identifying economy sector with a priority green direction is quite difficult, as it requires taking into account the prevailing conditions in each individual economic practice and defining specific criteria for the industry belonging to the priority in terms of green financing. Moreover, each economic policy should be based on the basis of those theoretical and methodological developments that will allow identifying the most effective mechanisms for increasing investment activity in the field of green projects. 
The sources of the formation of theoretical and methodological aspects of the green finance mechanism study include the works of academic economists in the mid-70s and 80s of the last century, when a group of Spanish economists led by H. Meadows presented a report to the Club of Rome on possible scenarios for economic development in the depletion of natural resources. Thirty years later, this group repeated the report, but already outlining the costs of lost time, monetizing the environmental costs (Meadows H. 2007) and thereby emphasizing the need for sufficient sources of funding. It is necessary to point out that there is still no unified understanding in the field of green finance, in this regard, the relevant subject of studies are processes to determine the composition and focus of green investment or investment in fixed assets aimed at environmental protection and rational use of natural resources. At the same time, we note that the key characteristic of green investment, in our view, can be considered the financing of projects aimed at preserving the environment and the transition to a low-carbon economy.

The study of practical experience of green finance can most often be connected with the launch of the issue of climate-oriented bonds by the European Investment Bank in 2007. The total issue amounted to more than 600 million dollars, and was offered with an AAA rating, for a period of 5 years. The designated bonds were used to finance projects to identify alternative energy sources and improve the energy efficiency of industrial production. The next issue of the green bonds was carried out by the International Bank for Reconstruction and Development (IBRD), a member of the World Bank Group, which in 2008 issued bonds specifically marked as green, and the procedure itself took place within the requirements established by experts at Norwegian University. The proceeds from the green bonds placement in the amount of SEK 2.85 billion were used to finance green projects in the agricultural sector, waste processing and forestry.

Assessing the current growth trends of the green finance market, we can draw attention to its tenfold growth only over the past 4-5 years. And in the period from 2021 to 2019, financial experts state an increase of almost 100 times, namely from 2.8 billion rubles.up to 261.3 billion dollars.

Moreover, among the issuers, large international financial institutions, as well as state and municipal authorities, set a precedent. Among them are: World Bank, European Investment Bank, governments of Poland, Germany, France; national banks: People's Bank of China, Bank of America; large corporations: Apple, Toyta, Engie; municipal and state institutions of different countries.

According to the Climate Bonds Initiative, which on February 14, 2020, released a review of key developments in green finance for January 2020 and noted that global green bond issuance was 14.3 billion dollars.

It should also be noted that in recent years non-financial corporations have become quite active in the process of green investing, the volume of emissions for the first quarter of 2021 is 8.6 billion dollars. In particular, the placement of green bonds of the Dutch company in the field of digital technologies Digital Dutch Finco BV in the amount of 1.6 billion dollars and the German energy company E.ON in the amount of 1.4 billion dollars took place.

Financial corporations attracted about 115.9 million dollars to the green market in January 2020. Experts pay special attention to such issuers as Japanese group of companies Orix and Austrian Raiffeisen Bank International, which have placed funds in environmental projects and development of capital-saving innovative technologies.

To identify the main areas and sectors of the economy in which green investment projects were carried out, CBI statistical information was studied, according to which in the first month of $2020,34 \%$ of the total emission of the month or 4.9 billion dollars was allocated to renewable energy projects, transportation -5.6 billion dollars, low-carbon construction -2.7 billion dollars, water -0.7 billion dollars, waste management -0.1 billion dollars. 


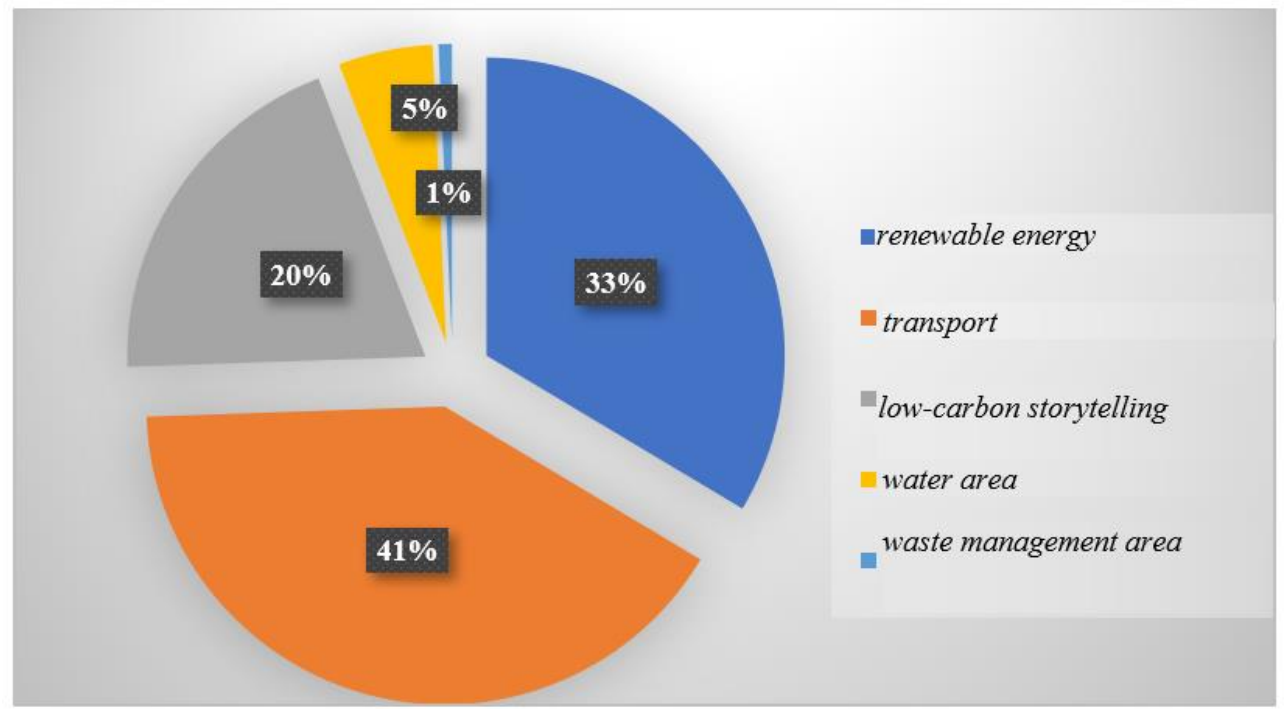

Fig. 1. Volume of emissions by industry and economy sectors in January 2021 (billion US dollars)

In January 2020, the American car manufacturer Porsche placed the first issue of green bonds in the amount of 1.1 billion dollars. The bond issue is certified in accordance with the CBI criteria in the field of Low Carbon Transport Criteria of the Climate Bonds Standard. Porsche is the first motor manufacturer to be certified according to the CBI criteria for lowcarbon vehicles. The funds from the issue will be used to finance the project for the manufacture of an all-electric sports car Porsche Taycan.

The first issues of green bonds in January 2020 were placed by the British electricity and gas company National Grid in the amount of 554 million dollars (the funds from the issue will be allocated to renewable energy projects), the Spanish corporation, which manages the national grid in Spain, Red Eléctrica in the amount of 775 million dollars. The funds from the bond issues will be used for renewable energy projects in the UK and Spain.

Earlier on January 16, 2020, the nonprofit green finance organization Climate Bonds Initiative released an overview of key green finance developments in 2019. The global volume of green bond issuance in 2019 was 254.9 billion dollars, which is $49 \%$ higher than in 2018, which was 171.1 billion dollars. Climate Bonds Initiative predicts growth of the total volume of global green bond issuance in 2020 to 350-400 dollars.

Thus, a review of global practices in green finance leads to the conclusion that today there is a rather different approach to the definition of industries and economy sectors, which can be classified as a priority in terms of green finance. And the generalization of the studied practice allows us to come to the following conclusions: in modern practice of finance, which can be attributed to a sustainable quite a lot. In particular, the leaders in the field of achieving the Millennium Development Goals, namely the Nordic countries and the EU have identified as a priority projects in the field of low-carbon economy and technology to ensure it. And in this regard, their national policy is also formed on the basis of these principles. Other countries, such as Kyrgyzstan, Kazakhstan, Russia, adhere to the principles of environmentally directed finance, that is, investment projects that address climate problems of a general nature. There are practices where the concept of green finance in its pure form is supported at the state level, namely the financing of projects ensuring the shift of the technological mode to innovative industry, and here we can list the experience of the Baltic countries. And no less relevant today is sustainable finance, which is focused on all projects related to the achievement of the Millennium Development Goals and sustainable 
development. Here we can highlight Japan, China, and undoubtedly Russia, which demonstrates a fairly high performance in programs to achieve the Sustainable Growth Goals.

The formation of conceptual framework of the green finance mechanism is largely determined by the policies implemented by global financial institutions. It is they who today act as a translator of the methodological foundations of financing in green projects and define the criteria indicators from the perspective of industry specific activities. At the same time, global financial institutions can suggest and provide recommendations into which sectors of the national economy are more profitable to implement green financing, both in terms of economic and environmental effect. Thus, in modern economic practice, the conceptual foundations of the development of the green mechanism of investment projects, first of all, should include the trajectory of the national economic policy, which was identified as priority areas of development and, of course, the specifics of sectoral structure of the national economy, according to which it is necessary to implement the green financing mechanism concept.

\section{References}

1. V.V. Archipova, Modern problems of development and prospects of reforming the global financial system (2016)

2. Report of the Intergovernmental Committee of Experts on Financing for Sustainable Development (2015)

3. "Green finance" in the world and Russia: monograph (2016)

4. E.M. Zomonova, Strategy of transition to "green" economy: experience and measurement methods (2015)

5. B. Porfiriev, World Economy and International Relations, 60(9), 5 (2016)

6. G. H. Brundtland, Our common future: Report of the World Commission on Environment and Development, 383 (1987)

7. W. D. Nordhaus, The American Economic Review, 67(1), 341 (1977)

8. Gary M. Anderson, History of Political Economy, 21(4), 641 (1989)

9. Mark Blaug, Great economists before Keynes: an introduction to the lives and works of one hundred great economists of the past (1986)

10. D. Acemoglu, J. Robinson, Why Nations Fail: The Origins of Power, Prosperity, and Poverty, 571 (2012)

11. K. Berensmann, N. Lindenberg, Green Finance: Actors, Challenges and Policy Recommendations, 23 (2016)

12. P. Dünhaupt, Financialization and the Crises of Capitalism, 67 (2016)

13. Mapping Channels to Mobilise Institutional Investment in Sustainable Energy. Green Finance and Investment (2015)

14. Mapping of Green Finance Delivered by IDFC Members in 2014. International Development Finance Club (IDFC) (2015)

15. M. Mazzucato, C. Perez, Innovation as Growth Policy: The Challenge for Europe. Science Policy Research Unit (SPRU): Working Paper Series (2014)

16. Weak Investment in Uncertain Times. World Bank Group (WBG), Global Economic Prospects (2017)

17. 2016 Biennial Assessment and Overview of Climate Finance Flows Report, UNFCCC Standing Committee on Finance (2016) 